\title{
Czego o portatywie i pozytywie historyk sztuki nie wie, a co wiedzieć powinien
}

CZEStAW GRAJEWSKI

INSTYTUT HISTORII SZTUKI UKSW

„Koń jaki jest, każdy widzi” - można przyjąć, iż ks. Benedykt Chmielowski, autor Nowych Aten, czyli pierwszej polskiej encyklopedii powszechnej, uznał konia za tak klopedii powszechnej, uznał konia za tak
znane zwierze, że nie widział sensu, by go znane zwierzę, że nie widział sensu, by go charakteryzować. Ten dość często przywoływany cytat służy na okreslenie rzeczy oczywistej, o której nie ma sensu dyskutoową słynną definicję konia w odniesieniu do pozycij banjo w USA ok. $1810 \mathrm{r}$. banjo jakie jest, każdy widzi" ${ }_{1}$. Wydawaby sie ż nie ma potrzeby opisywać ró niez nów, bo jakie sa każdy widzi, ale to będ now, bo jakie să, kazdy widzi, ale to blędn przekonanie. Istnieją bowiem instrumenty łudząco podobne do nich, które jednak organami nie są. Historyk sztuki ani typologii, ani historii organów czy wreszcie szczegółów konstrukcyjnych tego królewskiego instrumentu zapewne znać nie musi, wystarczy, że pozna ideę tzw, organów niebiańskich i piekielnych, niejednokrotnie obrazowanych w sztuce ${ }^{2}$. Ze względu

1A. Czech, Ordynacii itrędowaci. Spoteczne role instrumentów muzycznych, Gdańsk 2013, s. 190. 2 M. Zglińnski, O organach niebiańskich, piekielnych
zyce błazeńskiej co nieco, w: Initium sapientiae humilitas. Studia ofiarowane Profesorowi Jakubow jednak na to, że człowiek ograniczony jest precyzją pojęć, trzeba, by w analizach ikonograficznych używać właściwych nograficźn
określeń.

Z tego powodu pragnę skupić uwagę dwóch typach instrumentów, których klasyfikacja osobom nienawykłym do codziennego z nimi obcowania sprawia kłopot. Z jednej strony są to bowiem instrumenty z szeregami piszczałek i klawiaturą, z drugiej jednak ich wymiary na ogół nie są porównywalne z organami. Chcąc zatem pogodzić tę sprzeczność, w jakimś stopni po pę najczęsciej zdrobnier ak słusznie?

Podział na organy duże - stałe, oraz przenośne, mniejsze, dokonał się juz u schyłku średniowiecza, w XIV w. ${ }^{3}$ Wówczas pojawiły się trzy typy instrumentów należące do rodziny organów: portatyw, pozytyw i regał. Ten ostatni nie bedzie przedmiotem mojego artykułu z tej racii, że w sztukach plastycznych jest waściwie nieobecny Zainteresowany jodsłam do publikaci muzykologicznch, ktorych na ten temat jest już niemała liczba, także w języku polskim. Wszystkie

A. Skrodzka, współpraca A.S. Czyż, Warszawa 2015, s. $186-19$

J. Erdman, Organy. Poradnik dla u̇̇ytkowników

Warszawa $1992, s .12$
Dos eft hichominis fempercum tempoze labi: Et femper quadam conoicio

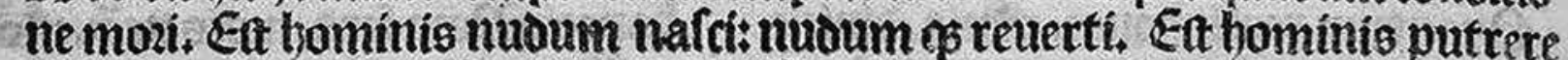
folo límum os fateri: Et miferis graolbus in cinerem reoigi. Fes et opes pre tantur ei: famulantur as bozam. Ectocuplex mane: befpere pauper erít.

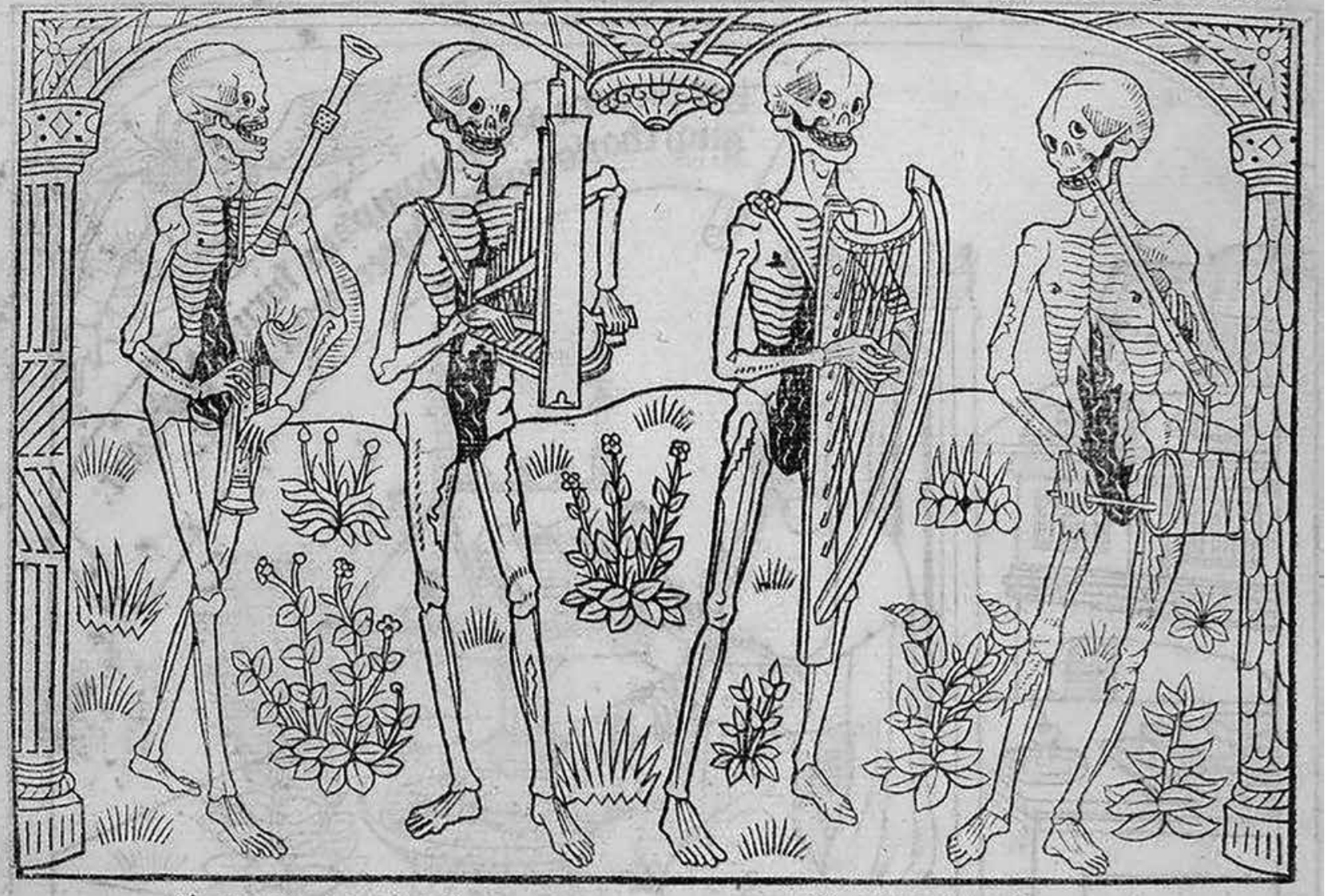

Le premier mort

Letiermort

1. La Danse macabre, wyd. Guy Marchant, 1486 Fot. domena publiczna

wymienione typy jako instrumenty mobilne łączy wspólna cecha: wyłącznie klawiatura ręczna (manuał) ${ }^{4}$

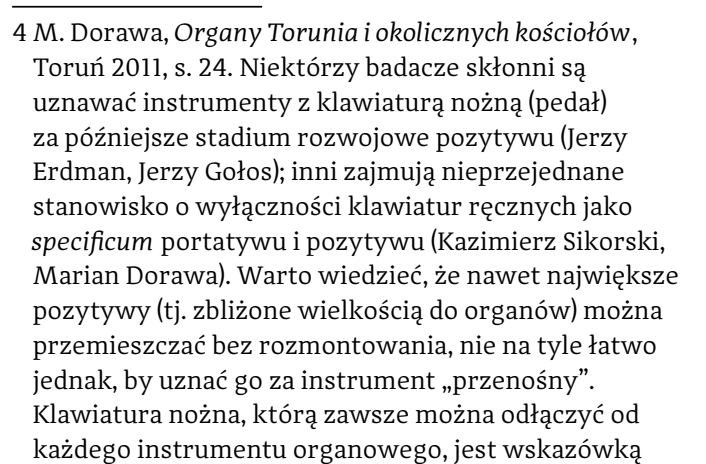

\section{PORTATYW}

Od wieków był to wdzięczny obiekt dla artystów. Liczba jego przedstawień zarówno w malarstwie ściennym, sztalugowym, rzeźbie, jak i iluminacjach wzrasta imponująco od XII w. Jest to niewielki instrument piszczałkowy, w miarę lekki, znakomicie sprawdzający się poza pomieszczeniem, np. podczas 
2. Rafael, Święta Cecylia ze św. Pawłem, św.Janem Ewangelista, św. Augustynem i św. Mariq Magdalena, $1518 \mathrm{r}$

Fot. domena publiczna

procesjis , stąd jego nazwa: portatiff, portative organ (łac. portare - nosić). Niewielkie rozmiary portatywu dobrze oddaje włos nazwa organetto. Nadawał się on także jako instrument do domowego muzykowa$n^{n i a}{ }^{6}$, zdwajając melodię w chansons bądź realizując jeden z głosów polifonicznego

Dążność do minimalizowania wymiarów i wagi instrumentu pociąga poważ ne ograniczenia muzyczne. Portatyw ma niewielką rozpiętość skalową (tj. niewielką liczbe klawiszy - zasadniczo dwie oktawy, niekiedy miej) i odpowiadająą im liczbe piszczalek ustawionych wednym lub dizóch rzędach? Z tego powc dwóch rzędach. Z tego powodu nie był uży wany wrze akordow (wykluczona zate jest funkcja akompaniamentu we współ czesnym rozumieniu). Do jego uruchomienia potrzebny był niewielki mieszek klinowy umieszczany za piszczałkami lub pod klawiaturą w taki sposób, by cały instrument mogła obsługiwać jedna osoba ${ }^{8}$ Z powszechnego użycia wyszedł w XVIU w, nie pozostawiwszy po sobie „następcy”, „kontynuatora”.

Przedstawienia malarskie portatywu są z pewnością dobrze znane, wszakż obecny jest w sztuce już od średniowiecz Warto zatrzymać się przy drzeworycie anonimowego artysty Les squelettes musiciens - Danse macabre, zamieszczonym

M. Drobner, Instrumentoznawstwo i akustyka, Kraków 1986, s. 186.

6J. Gołos, Polskie organy i muzyka organowa, Warszaw 1972, s. 24.

C. Sachs, Historia instrumentów muzycznych, thum

Jerzy Gołos niepotrzebnie komplikuje typologię instrujedno-i dwurecznych. Możliwość sry obiena rekam (ale nie koniecznośćl) sprawia, że do obstugi instrumentu potrzebna jest druga osoba i ta cecha wystarczy do uznania takowego instrumentu za pozytyw, niezależnie od jego wielkości i stopnia mobilność Marchanta z 1486 r. (il. 1).

Trzeba podkreślić - z muzykologicznego punktu widzenia - wyjątkowość tego przedstawienia. Historyk sztuki widzi w nim przede wszystkim dzieło stworzone w nurcie sztuki wanitatywnej. Muzykolog natomiast zauważy bez trudu, że instrumenty trzymane przez trzy szkielety (pierwszy od lewej, trzeci i ostatni) są przedstawicielami głównych rodzin instrumentologicznych, tj. aerofonów, chordofonów i idiofonów. W portatywie, trzymanym przez drugi szkielet, można słusznie upatrywać symbolu muzhi sakranie ralnej, ale jownie dobrze można widzieć w nim przew kwestii przyporządkowania instrumentów klawiszowych, które pod koniec średniowiecza coraz śmielej wkraczały do której rodziny instrumentologicznej zaliczyć portatyw: instrumentów strunowych, detych czy perkusyjnych, artysta zwyczajnie stworzył czwarta rodzinę - instrumentów klawszowych, zapewne mając świadotow ke istnienia juz in mośc istnienia już innego instrumentu klawiszowego, klawikordu, jednego z bardzo niewielu instrumentów skonstruowanych od podstaw w Europie już w XIV w." Powszechnie znane przedstawienie portatywu widnieje na słynnym obrazie Rafaela z 1518 r. ukazującym świętych, w tym św. Cecylię (il. 2). Wypadające

10 Cz. Grajewski, Instrument organowy w perspektywie szt 34 .

owe chordofony uderzane powstaty, jak sie wydaje, w 2. poł. XIV w. Pierwsze przedstawienia ikonograficzne klawikordu pochodzą z okresu

1400-1450, a więc niewiele pożliej od momentu

źródła ikonograficzne tego instrumentu pochodza głównie z Anglii, Francji i dzisiejszych terenów Holandii, można przyjąc, iż klawikord narodził się prawdopodobnie w póthocno-zachodniej Europie.
B. Brauchli, The Clavichord, Cambridge 1998, s. 281. w druku francuskiego wydawcy Guy jaw rozterek ówczesnych teoretyków świątyñ ${ }^{10}$. Nie mogąc zdecydować się, do

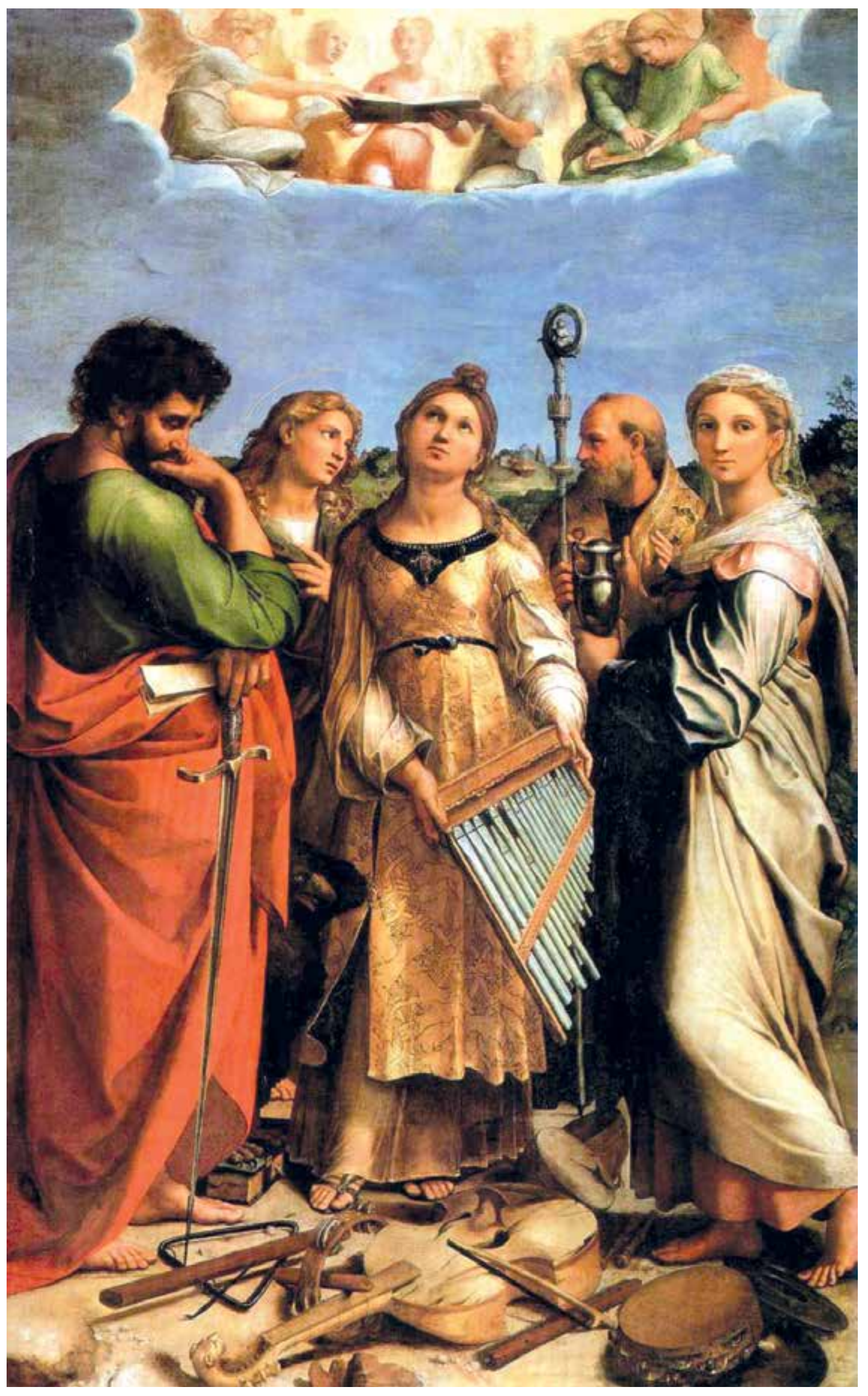




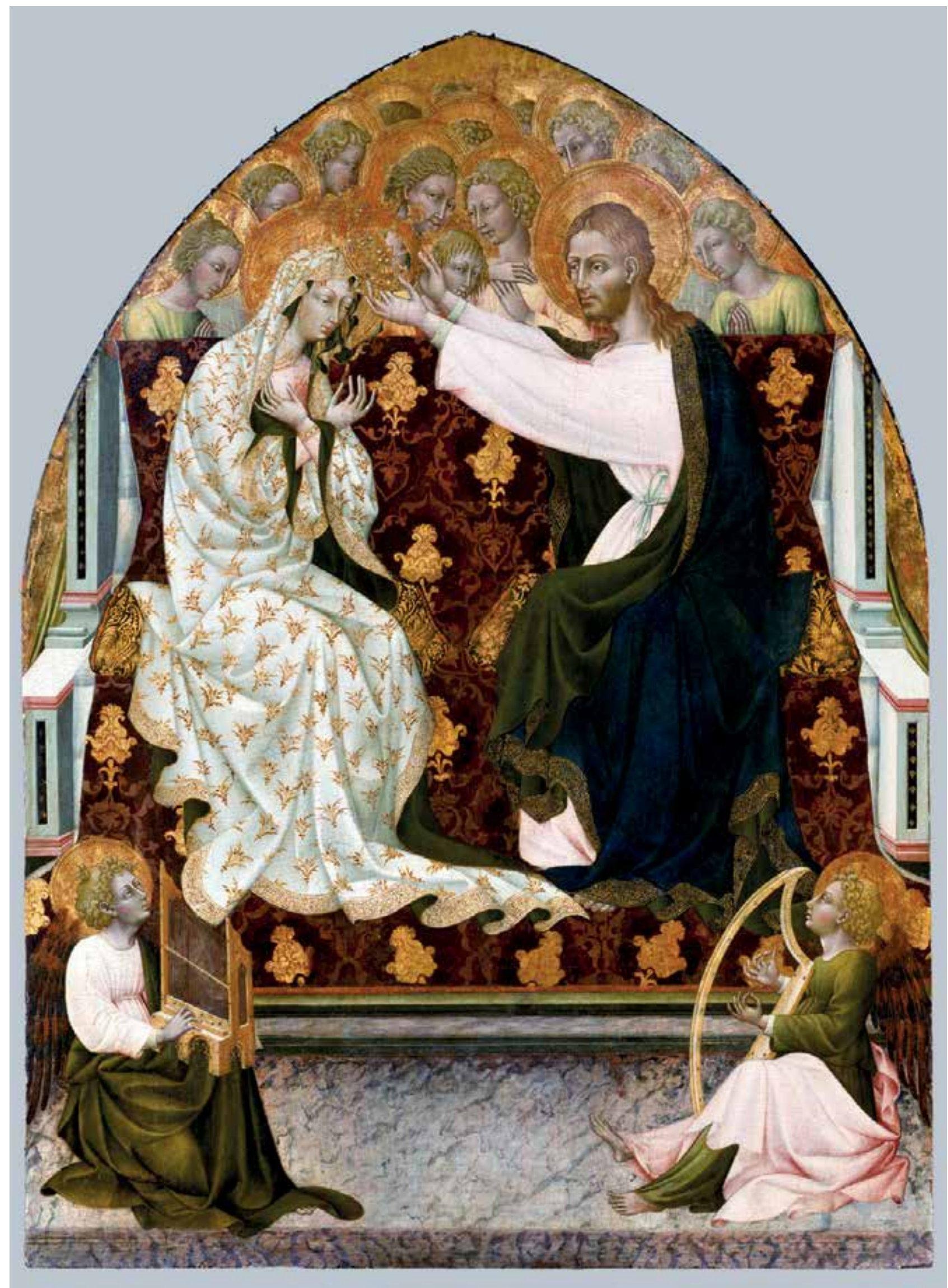

3. Giovanni di Paolo, Koronacja Maryi, ok. 1455 r. Fot. The Metropolitan Museum of Art, Nowy Jork

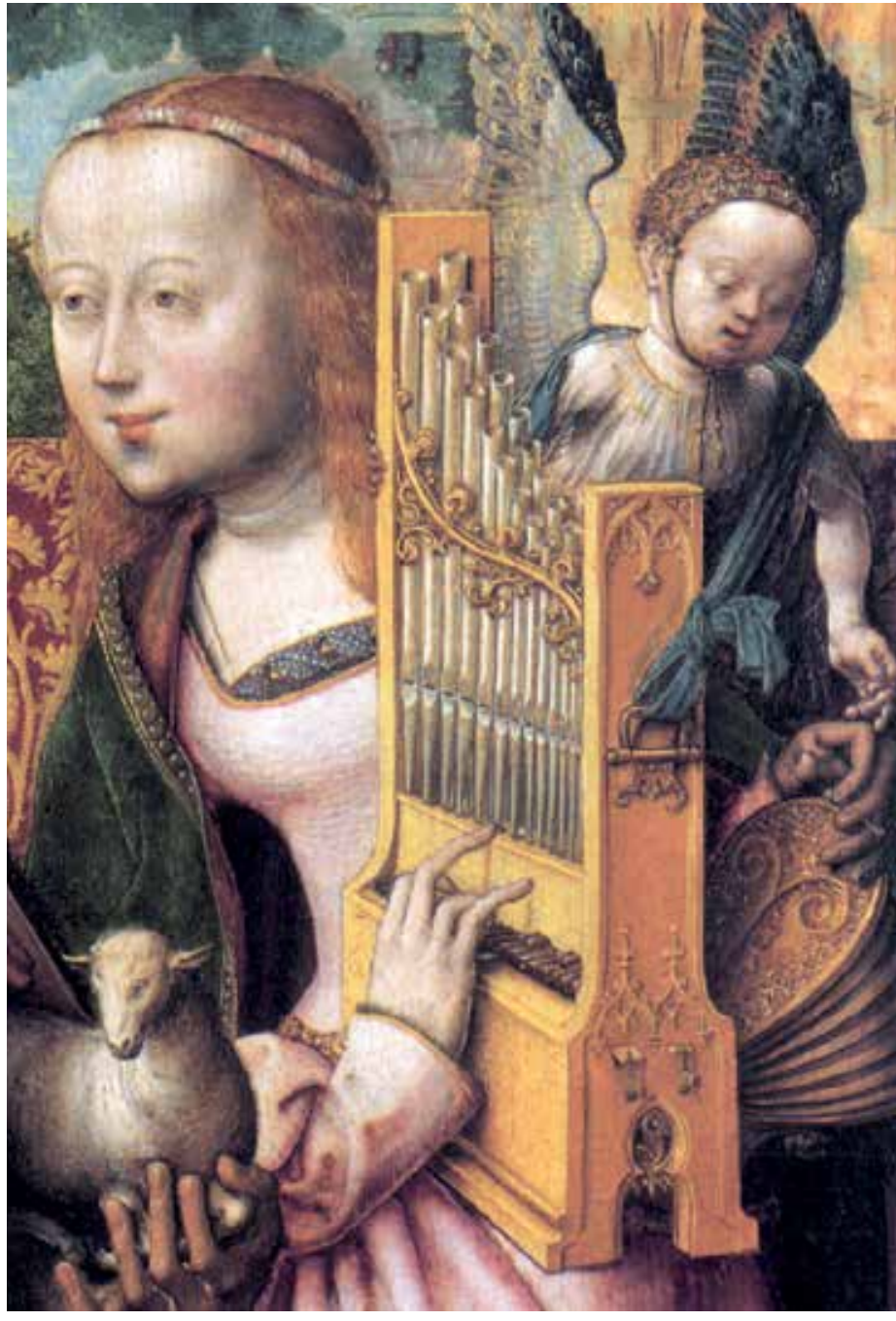

4. Fragment tryptyku Ukrzyżowania Mistrza św. Cecylii, 1490-1495. Fot. domena publiczna

trzymanego przez nią instrumentu piszczałki oczywiście podkreślają uniesienie męczenniczki. Wydaje się, że Cecylia zasłumęczenniczki. Wydaje się, że Cecylia zasłutyw, który trzyma w dłoniach, i za chwile znajdzie się on obok leżących już na ziemi zniszczonych instrumentów $w^{12}$. Jest on rzecz jasna symbolem muzyki niebiańskiej, której

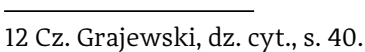

nie można doświadczyć sensualnie. Artysta umieścił portatyw pomiędzy niebem i ziemią - nie na ziemi obok innych instrumentów symbolizujacych muzykę świecką, ale też nie w niebie, obok śpiewających aniołów - podkreślając, że portatyw jest wykonany z materii, której w niebie wszak nie ma. Znanych przedstawień porzatywu est oczywiście więcej. Jednym z najstarszych (ok. 1455 ) jęcej. Jednym z najstarGiovanniego di. Paolo (il. 3). Wśród dzieł nieco tylko późniejszych wymienić należy szeroko znane Muzykujace anioły Hansa

Memlinga (ok. 1485 r.) i św. Cecylię grającą Memling (0k 1485 $\mathrm{r}$ ) Mistrza Oltarza sw. Bartlomieja (il. 4). Mistrza OHtarza sw. Bartomieja(li. 4). To ostatne dzleło sztuki przedstawia portatyw z dwoma rzędami piszczałek metalowych. Warto zauważyć, że święta sama obsługuje mieszek - lewą ręką pompuje powietrze do wiatrownicy (drewniane szczelnej skrzynki, na wierzchu której w otworach umieszczone są piszczałki). Klawisze są oczywiście mniejsze niż we współczesnych instrumeach ale tez portatywie grato się inną techniką, niz portatywie gralo sie in za tech nik niz obecnie, wykorzystując zaledwie palce wskazujący i środkowy. Instrument był niezbyt poręczny właśnie z powodu wymuszania dość niewygodnej pozycji dłoni, kiedy muzyk gra na instrumencie zawieszonym na przedramieniu ${ }^{13}$.

\section{POZYTYW}

Jest to większy instrument od portatywu ma również znacznie szersze możliwości muzyczne (klawiatura nierzadko liczy już cztery oktawy). Występuje w kilku wariantach: jedno- lub dwuczęściowy oraz tzw. szkatulny. Nadawał się doskonale do kaplic, niewielkich kościołów a nawet większych sal i pokojów. Pozytyw o pokaźniejszych rozmiarach stawiany był na podłodze; mniejszy zaś na stole. Początkowo

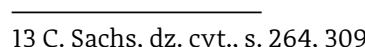


miał jedną klawiaturę ręczną (tzw. manuał). W odróżnieniu od portatywu, obsługiwały go dwie osoby: organista (grający obiema rękami siedząc przy pozytywie) oraz kalikant osoba pompujaca powietrze do instrumentu umieszczonym z tyłu mieszkiem. W pozytywie szkatulnym artysta mógł bez pomocy drugiej osoby uruchomić instrument, obsługując stopą dźwignię połączoną z miechem w dolnej części pozytywu.

Pozytyw o wiele rzadziej niż portatyw był obiektem zainteresowań artystów. Prawdopodobnie najbardziej znanym jego malarskim przedstawieniem jest scena malarskim z prawego skrzydra tryptyku z kościoła
pw. św. Bawona w Gandawie (1432) autorpw. św. Bawona w Gandawie (1432) autor stwa Huberta i Jana van Eycków (il. 5). Pozytyw nie otrzymał nazwy jako przeciwstawienie domniemanego „negatywu". Za źródłosłów tego terminu najczęściej uważa się łacińskie słowo ponere („w miejscu"). Oznaczałby zatem instrument, którego z zasady się nie przenosi. Oczywiście pozyzywy budowane były w różnych wielkościach (w rozumieniu muzycznym i fizyczsciach (w rozumieniu muzycznym ${ }^{44}$. Generalnie jednak nie były to
ny nym $)^{14}$. Generalnie jednak nie były to
instrumenty, które spełniałyby rolę, do jakiej skonstruowano portatyw (il. 6). W epoce renesansu i baroku pozytywy były wykorzystywane podczas wielu uroczystości, przede wszystkim religijnych, ale znalazły zastosowanie także w sferze świeckiej. Na progu XVII w., kiedy pojawił się nowy gatunek muzyczny

14 Przykładowy pozytyw można ogląadać w Muzeum Ziemi Lubawskiej w Nowym Mieście Lubawskim. Jest to jednomanuałowy, trzygłosowy pozytyw o regular-
nej, czterooktawowej skali, bez klawiatury nożej stawiany na podłodze. Zabytek został wprowadzony do ewidencii w 1959 r., gdy otwierano muzeum, przekazano doń ten instrument pochodzący
prawdopodobnie z nieopodal położonej miejscowośc

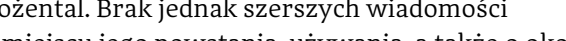
o miejscu jego powstania, używania, a także
nościach przekazania eksponatu do zbiorów muzealnych. Cz. Grajewski, Nieznany instrument organowy z Nowego Miasta Lubawskkiego, , ,Seminare,
Poszukiwania naukowe" 2009, t. 26, s. 319-323.

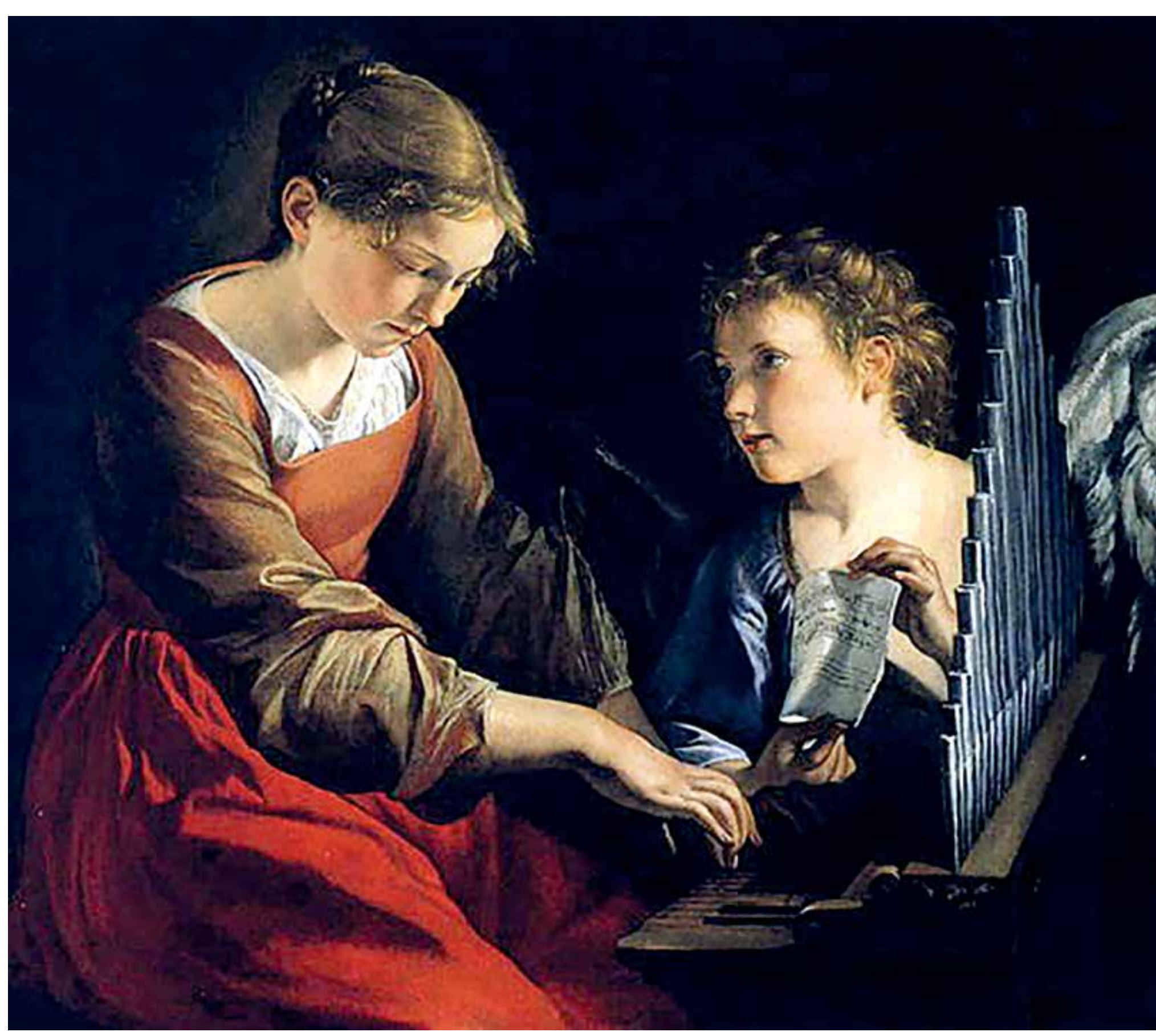

6. Orazio Gentileschi, Święta Cecylia z aniołem, ok. 1617 r. Fot. domena publiczna

- opera, wchodziły w skład kapel instrumentalnych w pierwszych przedstawieniach Jacopo Periego (1561-1633) i Claudia Monteverdiega (1567-1643). Pozytyw nie Mydawa zbyt glosno dź wy kach XVII i XVIII służył do realizacji szcze-
gólnego rodzaju akompaniamentu, tzw. basu cyfrowanego. Wyszedł z użycia wraz z odejściem tej techniki ${ }^{15}$.

W tym kontekście warto zwrócić uwage na źródła historyczne, jakimi są parafialne księgi rachunkowe, dotąd pomijane

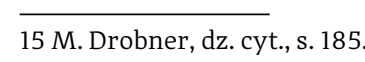




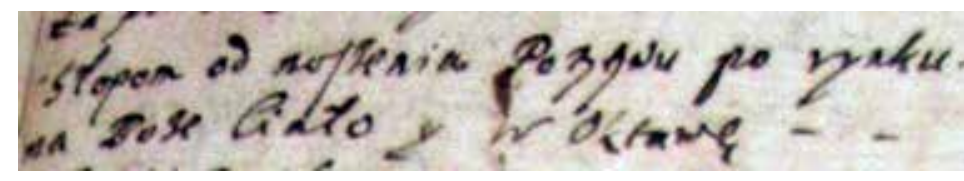

7. Wypis z Expensa pecuniae... klasztoru Bożego Ciała

na Kazimierzu w Krakowie, $1616-1676$, s. 125

nawet przez badaczy historii Kościoła. Oto bowiem w księdze przychodów irozchodów z lat 1616-1676, pochodzącej z kościoła kanoników regularnych laterańskich pw. Bożego Ciała na Kazimierzu w Krakowie, znajduje cię szereg wiśs dotyczących u̇y thowasię szere nia pozyty wu. Piewszy taki zapis dokonany został w roku 1668. Wynika z niego, że zakrystian wypłacił świeckim mężczyzno niewielkie kwoty za przenoszenie instrumentu podczas procesji Bożego Ciała ${ }^{16}$.

Pozytyw, o którym wzmiankuje dokument, raczej nie był zbyt masywny, skoro przenoszony był podczas procesji. Jeżeli do gry ustawiano go na niewielkim stole, $i$ te trzeba było przenosić między stacjami. Wspomniany w księdze pozytyw można Wsponnian wyobrazić sobie, kontemplując np. obraz Orazia Gentileschiego (il. 6).

We wzmiance tej na pozór nie kryje się nic szczególnie interesującego. History sztuki może się jedynie zdziwić, dlaczego w procesji noszono pozytyw, wyglądający jak niewielkie organy, skoro do uświetnienia uroczystości można było zatrudnić choćby niewielką kapele instrumentalną. Muzykolog zaś wyjaśni, że w tamtymą

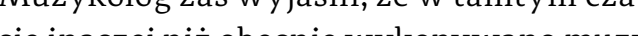
sie inaczej niź obecnie wykonywano muzykę liturgiczną. Spiew chorałowy (łacińs realizowany był bez akompaniament przez scholę gregoriańską kierowaną przez kantora. Pozytyw nie służył - jak dzisiaj organy - do akompaniamentu śpiewu

16 "Chłopom od noszenia pozytywu po rynku gr. 20". Expensa pecuniae thesaurii sacrarii Ecclesiae S[anci S[simi] Corporis Christiper me Platrem]Joannem Gelasium Sacristianum adnotata 1616-1676, Archiw
Kościoła Bożego Ciała Kraków, brak sygn. s. 119 . ogółu wiernych. Organista grający na pozytywie realizował akompaniament w zespołowej muzyce instrumentalnej bądź wokalno-instrumentalnej. Pozytyw używanybyłwiç wrolinstum by wiec w roli ins jako pełnoprawny sktadnik kapell. To, że taka orkiestra (kapela) brała udział w największych uroczystościach parafialnych, potwierdzają wypłaty odnotowane we wspomnianej księdze rachunkowej już

w następnym roku 1669: „chłopom od noszenia pozytywu po Rynku w dzień Bożego

Ciała y w oktawe" (il. 7) oraz poniżej: Muzyce przez oktawę Bożego Ciała zł. 19 gr. Praktyka ta trwata nieprzerwanie do roku .

Wzmiankowany w dokumencie pozytyw niemal na pewno był wykorzystywany do realizacjibasso continuo, czyli stanowił rzeczywisty element kapeli instrumentalnej, chociaż nie pełnił roli akompaniamentu do śpiewu (inaczej niż organy w obecnej liturgii). Pewnośc te zyskujemy, studiując cabośc wpisów we wspomnianej księdze rachunkow. kontekście jako światli mecenasi kultury, nieszczędzący środków finansowych na upiększenie muzyką liturgii. Instrumentaliści brali udział w największych uroczystościach: poza Bożym Ciałem, także w Wielki Piątek (!), czy też w uroczystość odpustową św. Augustyna. Pozytyw był zatem konieczny do wykonania utworów instrumentalnych (bądź wokalno-instrumentalnych) przy każdej zerterech zezterech sta Ciala. Dbalośc kanoników regularnych laterańskich o splendor uroczystości nie dziwi, wszak procesja ta odbywała się w dzien głównego odpustu parafialnego. Jednocześnie pierwsza połowa XVII w. to czas, kiedy europejskie kręgi muzyczne wręcz zachłysnęły się nowoczesną muzyką w stylu koncertowym, który pod koniec XVI w, powstal

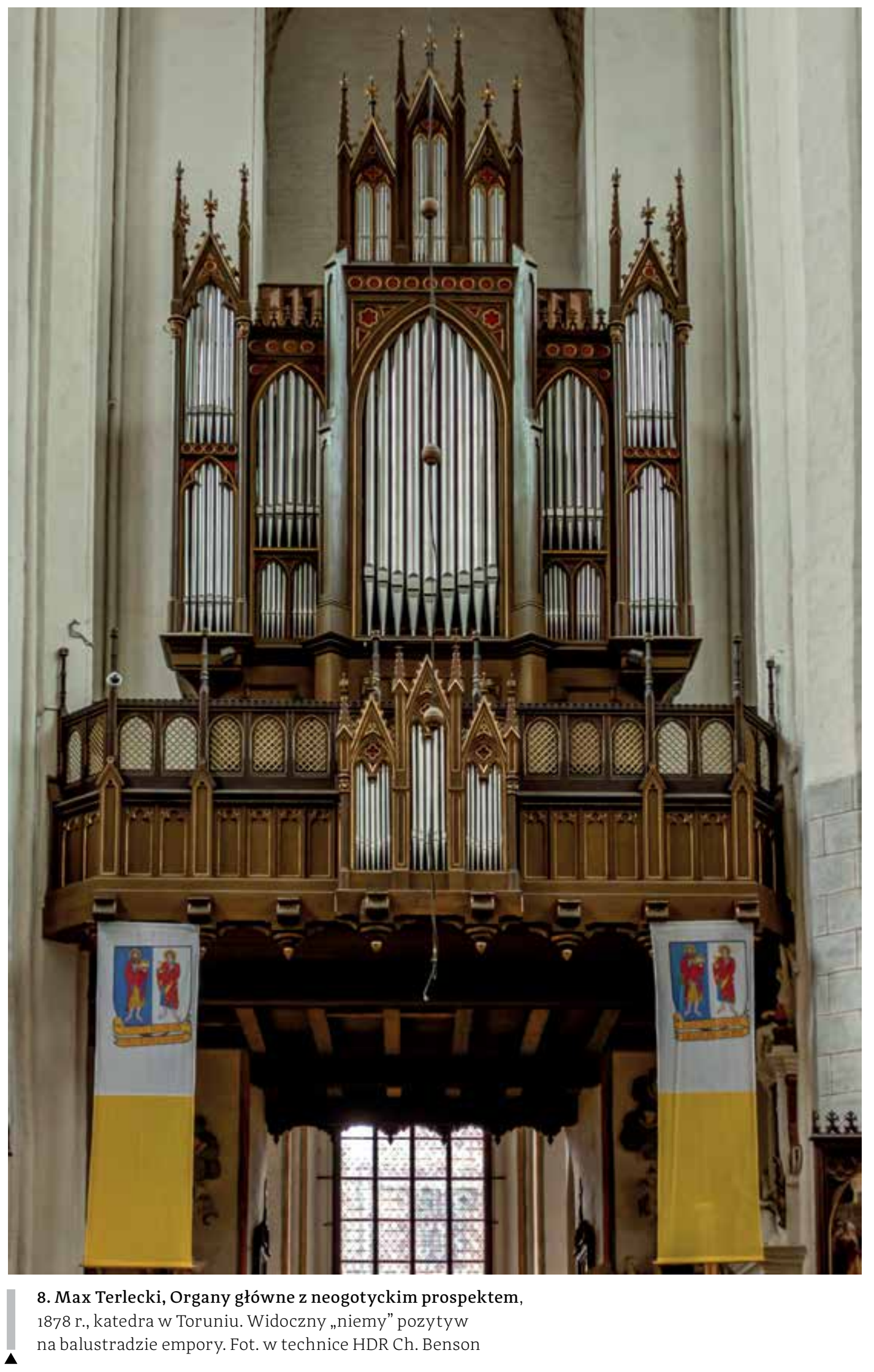


rozwinął się w bazylice św. Marka w Wenecji i dotarł dość wcześnie do liczkontynentu, w tym także Była to muzyka, jakiej dotąd nie można było doświadczyć, piękna, bogata barwna i wzruszająca, ale, co ważniejsze, wymagająca użycia instrumentu zdolnego do gry akordowej, np. klawesynu lub właśnie pozytywu. Można sobie z łatwością wyobrazić wykonanie przy każdej stacji motetu eucharystycznego w stylu koncertowym (z udziałem solisty/solistów wokalistów) bądź utworu czysto instrumentalnego, tzw. sinfonii, jak w epoce baroku określano zbiorczo utwory instrumentalne. Pozornie niewiele znaczaca wzmianka o przenoszeniu pozytywu świadczy zatem o przenoszeniu pozytywu świadczy zatem o wysokiej kulturze muzycznej zakonu i miasta, wskazując, że w epoce baroku muzycy polscy utrzymywali ścisły kontakt z muzyczną awangardą Europy.

Powyższe rozważania o pozytywie odnosza sie do podstawowego, ale nie jedynego rozumienia tego terminu. W drugim znaczeniu pozytyw jest muzyczide iarchizelonicznie wyct tektonicznie wydzielona sekcja wiekich organów, zawieszaną na balustradzie empory. Wizualnie sekcja ta stanowi pomniejszoną wersję prospektu organów głównych (il. 8). Przykładów takiego rozwiązania, charakterystycznego zwłaszcza dla barokowego budownictwa organowego, jest bardzo wiele również w Polsce. Jerzy Gołos sądzi, że idea ta powstała z połaczenia w jeden instrument pierwotnie obecnego na den instrument pierwotnie ober enporze tylko pozytywu (tzw. orgar nia chórowi) z instalowanymi następnie

18 Pierwszym drukiem muzycznym kompozytora polskiego wydanym za granicą są Offertoria etcommuniones totius anni Mikołaja Zieleńskieg prymasa Wojciecha Baranowskiego, na którego dworze w Łowiczu Zieleński pełnił funkcję kapelmistrza. Część z tych utworów (offertoria) skomponowa-

na jest właśnie w nowoczesnym na owe czasy. organami głównymi' ${ }^{19}$. Niekiedy taki pozytyw był tylko dekoracja, atrapa, z zastosowaniem prawdziwych piszczałek bądźich mitacji. Tak rozumiany pozytyw nie jest jednak przedmiotem niniejszego artykutu.

PRAWIDLOWE ODWZOROWANIA

\section{Na zakóncenie warto wskazać na -} hyba zbyt rzadko podnoszoną - kwestię prawidłowości odwzorowania w sztuce obu opisanych instrumentów. Szkoda, że tak mało miejsca poświęca się temu zagadnieniu, bo historycy sztuki mieliby pewnośc, czy artysta malujac lub rzeźbiąc np porta(ąc np. portaiczym model, czy zeciwnie: tworzył z pamięci.

Pomocą w rozstrzygnięciu tego dylematu jest oczywisty stosunek długości do częstotliwości fali akustycznej. Wiadomo, że im fala dłuższa (tj. dłuższa struna chordofonu, wyższy słup powietrza w aerofonie), tym niższa jej częstotliwość (a więc niższy dźwięk). Stąad właśnie dźwięki niższe znajdują się wdole klawiatury (po lewe stronie) a wyżze w gérze. Prawidlowo zatem wystad Proje piszczałki (lub struny) od strony lewej, które stopniowo zmniejszają się w kierunk na prawo. Przy tak przyjętym systemie uszeregowania dźwięków na odwrotnie skonstruowanym instrumencie nie dałoby się grać, aczkolwiek dźwięki dałoby się zen wydobyć.

A jak się to ma do sztuki? Większość przytoczonych dzieł malarstwa, tj obraz Koronacja Maryi Giovanniego di Paolo (it, wizerunki św. Cecylii z tryptyku Mistrza Ołtarza św. Bartłomieja (il. 4) oraz ołtarz Huberta i Jana van Eycków (il. 5), jest przykładem prawidłowego odwzorowania instrumentu - piszczałki ułożone są malejąco w prawo. Nieprawidłowo natomiast został niestety ukazany portatyw na słynnym Rafaelowskim wizerunku św. Cecylii (il. 2).

$\overline{19 \mathrm{~J} \cdot \text { Gotos, dz cyt s. } 25 .}$

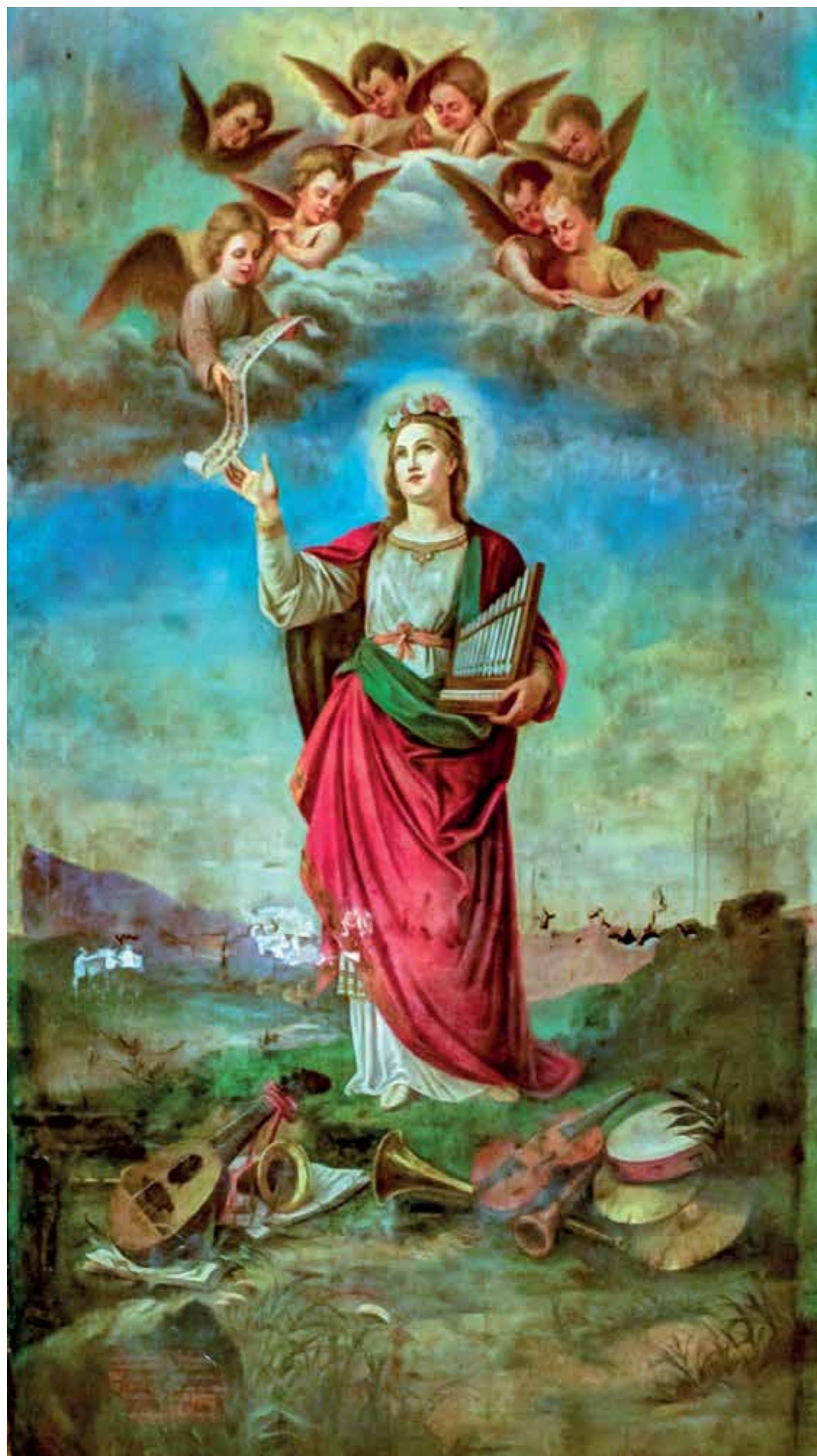


Z informacji przekazanej przez Giorgia Vasariego wynika, że wszystkie instrumenty muzyczne, włacznie z portatywem, zostały namalowane nie przez

Rafaela, lecz na prośbę mistrza, przez jego ucznia, Giovanniego da Udine ${ }^{20}$. Jednak nie on pierwszy w historii i zapewne nie ostatn odwrócił kierunek piszczałek. Wystarczy spojrzeć na XIX-wieczny olejny obraz św. Cecylii nieznanego artysty, wiszący w toruńskiej katedrze pw. śś. Janów (il. g). Sądz że fenomen ten ma prozaiczne źródło - niedoskonałą pamieć artysty, a także niekied wpływ przekazów graficznych. Warto zawplyw przekazow graczich a zauw wien w zależności od kierunku patrzenia widzi się rząd piszczałek zmniejszający swą wysokość w lewo bądź w prawo.

Można ulec pokusie dostrzeżenia

w nieprawidłowym odwzorowaniu piszczałek instrumentu jakiejś negatywnej symboliki, ukrytego przekazu czy znaczenia. Po głębszym jednak zastanowieniu myśl taką nalėy porzucić Po pierwsze, nie

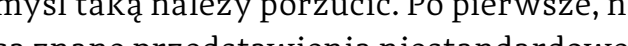
są znane przedstawienia niestandardowe budowy innych instrumentow inie da sie w żaden przekonujący sposób wyjaśnić, dlaczego jedynie instrument piszczałkow byłby „podatny” na tak negatywny przekaz Po drugie, instrument muzyczny sam w sobie jest moralnie obojętny, tzn. nie jest ani dobry ani zły. Dopiero muzykę na nim tworzoną można ocenić jako godną lub nie miejsc i czynności świętych.

Owszem, historia sztuki zna przykłady przedstawień instrumentów organowych (ogólnie) w kontekstach negatywnych. Na organach grają postaci źle się kojarzące: personifikacje wad i grzechów, a nawet sami mieszkańcy piekła, z piszczalek zas wydobywa się muzyka rzeczywiści diabelska (odwzorowana w formie szar

z bluźnierczymi napisami $)^{21}$. Podobny przykład widzimy w kościele w Harnevi (Szwecja) - jest to fresk autorstwa Alberta ictora (ok 1480) przedstawiający świnię rająca na małym instrumencie organowym (najprawdopodobniej pozytywie). wym (najprawdopodobniej pozytywie). Te i inne, zapewne liczne przykłady zawieraja przesłanie symboliczne, niemniej konstrukcja instrumentu nie należy do istoty przekazu. Albert Pictor ideę profanacji muzyki sakralnej (organy przecież są symbolem muzyki kościelnej) oddałby równie dobrze, niezależnie od tego, jak namalowałby (de facto namalował je prawidłowo).

Pozostaje jeszcze kwestia kierunku piszczałek w pozytywie przedstawionym na obrazie Orazia Gentileschiego (il. 6). Nie ma wątpliwości, że symetryczne ustawieni piszczałek w instrumentach organowych zawsze było możliwe i przykładów zastosowania takiego rozwiązania jest wystarczająco wiele. Dylemat, czy układ piszczałek powinien być symetryczny, czy też tworzyć dnolierunkowy szereg, by natury este-

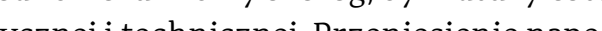
z klawisza na zaw r powetrzy pod pęuzlawisza na zawor powietrzny pod piszczalką wymagało zastosowania odpowiedniej liczby kątowników, dźwigni, popychaczy i innych mechanicznych elementów sterowania dźwiękiem, tzw. traktury. Im większą odległość od klawisza do piszczałk konstruktor miał do pokonania, tym większą liczbę elementów musiał zastosować. Dile jednak w wielkich organach kościelOych takie rozwazanie bylo wręcz konjecznych takie r mostią (wielkosc instrumentu wymuszała wszak stosowanie wielosci elenentow traktury), o tyle w małych instrumentach stawało się zbędną komplikacją.

Na zakończenie autor pragnie wyjawic zamysł kompozycyjny niniejszego tekstu. Zamysł, mający na celu powiązanie w jednym tekście dzieł sztuki malarskiej i muzycznej,

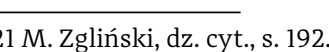

zwłaszcza dawnej, z osobą ks. prof. Janusza Stanisława Pasierba. Otóż w 1988 r., na odbywającym się w Uniwersytecie we Fryburgu wampezjum Rady Europy i UNESCO Ku sympoz) ma Rady Europyiunesco Ksiadz Profesor wzbudzll zachwy zgromadzonej publiczności wygloszonym referatem na temat oblicza europejskiej kultury. Stwierdził w nim dobitnie, że w średniowieczu Europa rozciągała się tak daleko, pokąd sięgały katedr $\mathrm{y}^{22}$, będące jej symbolem. Dla Europejczyków zaś organy już od dziesięciu wieków są wręcz niezbywalnym elementem wyposażenia katedrª ${ }^{23}$ i symbolem muzyki sakralnej.

WHAT ART HISTORIANS DO NOT

KNOW BUT SHOULD KNOW ABOUT

PORTATIVE ORGAN AND POSITIVE

ORGAN

\section{CZESŁAW GRAJEWSKI}

The author briefly describes the history and use in music of two organ-type instruments: a portative organ and a positive organ. He shows the difference in construction between the two and the characteristic features that allow to identify both types in old painting. An important feature of both instruments is the arrangement of the pipes. In the painting we can see two possibilities: from the left to the right side, the height of the pipes may decrease or increase. An accurate depiction would (always) show the pipe row decreasing from left to right.

\section{StOWA KLUCZOWE / KEYWORDS:}

portatyw, pozytyw, instrumenty

muzyczne, malarstwo

portative organ, positive organ, musical

instruments, painting

22 J.St. Pasierb, Katedra symbol Europy. La cathedrale

Europe, Pelplin 2003, s. 8.

23 M. Dorawa, dz. cyt., s. 22 